\title{
コンクリート柱に水平に埋込んだ異形鉄筋の付着強度

\author{
BOND STRENGTH OF DEFORMED BARS BURIED \\ HORIZONTALLY IN CONCRETE COLUMN
}

関

博*・赤 塚 雄 三**

By Hiroshi Seki and Yuzo Akatsuka

要 旨 コンクリートの打上り高さが, 水平に埋込 んだ異形鉄筋とコンクリートとの付着強度におよぼす影 響を明らかにするために一連の実験を行なった。第 1 に 鉄筋を上下層に水平に埋込んで $15 \times 15 \times 30 \mathrm{~cm}$ の供試 体を用い，上下層の鉄筋の付着強度比がほぼ $70 \%$ であ ることを示した。つぎに, この付着強度の低下はブリー ジングによるものであると想定し，ブリージングに影響 をおよぼすと考えられる, セメントの品質, 細骨材粒 度, コンクリートのスランプ, コンクリートの強度, 鉄 筋等の因子をそれぞれ 2 種選択し， $15 \times 15 \times 180 \mathrm{~cm}$ の コンクリート柱を用いて付着強度を求めるとともに, 各 層の $\phi 15 \times 180 \mathrm{~cm}$ の供試体を用いてブリージングおよ び圧縮強度の変化を調べた。この結果圧縮および付着強 度の低下は, コンクリート柱の上部 $0 \sim 60 \mathrm{~cm}$ 程度の表 層に限定される現象であることを明らかにした。

\section{1. まえがき}

異形鉄筋とコンクリートとの付着強度はその配筋箇所 に応じて変化する。同一コンクリート内であっても上方 に水平に埋込まれた鉄筋（以下これを水平上筋と呼ぶ） と下方に水平に埋込まれた鉄筋（以下これを水平下筋と 呼ぶ）とではその付着強度が異なることが知られている が，その程度の評価については, 資料は必ずしも十分で ないようである。

港湾構造物における異形鉄筋使用状況の調査結果 ${ }^{1)}$ に よると, ケーソン等では, コンクリートの 1 回の打上り 高さは概して大きく, $3.6 \mathrm{~m}$ におよぶ例もあった。この 種の構造物では, 部材断面が概して小さい壁状の部材が 多く， スランプ $10 \sim 15 \mathrm{~cm}$ 程度のコンクリートを使用 し，その締固めには内部振動機（棒状）を用いている例 が大部分である。したがって, 水平上筋とコンクリート との付着強度は水平下筋にくらべてかなり減少するもの

\begin{tabular}{ll}
\hline$*$ 正会員 & 運輸省港湾技術研究所 研究員 \\
** 正会員 & 工博 \\
運輸省前港湾技術研究所
\end{tabular}

と予想されるが，施工上これを防止する適当な方法もな いのが実情である。このような観点から，打上り高さが ブリージングおよび付着強度におよぼす影響について調 査し, 一回の打上りの許容高さないし, 許容付着応力度 について検討する必要が認められた。

一回の打上り高さが大きい場合のコンクリートと異形 鉄筋との付着強度の関係に関しては, 数例の研究成果が 報告 $^{2)}{ }^{3)}$ されているが，供試コンクリートの柱状が一般 の土木工事に使用されているコンクリートの性状とか なり異なり，あまり参考にならない。そこで本研究 で は, 圧縮強度 $250 \sim 350 \mathrm{~kg} / \mathrm{cm}^{2}$, スランプ $10 \mathrm{~cm}$ 以下の コンクリートを対象として一連の実験を行なった。すな わち, シリーズIの実験では $15 \times 15 \times 30 \mathrm{~cm}$ の供試体と 表面形状や断面形状等の相違する 15 種の高張力異形鉄 筋を用いて水平上筋, 水平下筋の付着試験を行なって, 上下層における付着強度比の一般的傾向を調べた。シ リーズIの実験では，2種の異形鉄筋を使用し，コンク リートの打上り高さを $30 \mathrm{~cm}$ および $180 \mathrm{~cm}$ の 2 種に 変え, 付着強度を低下させると考えられる 4 因子を選定 して, 打上り高さの大きいコンクリートに打け付着強 度低下の現象を実験的に調べた。

なお，本文は港湾技術研究所報告 5 巻 15 号 $^{1)}$ と 7 巻 1 号 $^{4)}$ に発表した論文の一部を要約したものである。

\section{2. 試験 方法}

\section{(1) 試験の概要}

シリーズ Iの実験では，コンクリート強度を $\sigma_{28}=280$ $\mathrm{kg} / \mathrm{cm}^{2}$, スランプをほぼ $8.5 \mathrm{~cm}$ とし $15 \times 15 \times 30 \mathrm{~cm}$ の 供試体と 15 種類の鉄筋を用いた。水平上筋および水平 下筋の下面のコンクリート層は，それぞれ $22.5 \mathrm{~cm}$ お よび $7.5 \mathrm{~cm}$ であり,これら鉄筋とコンクリートとの付 着強度を比較した。

シリーズாにおいては，コンクリートの打上り高さに 
よる付着強度の変化は主としてブリージングの影響によ るものと考え, ブリージングに影響する主要な要因とし てセメントの品質, 細骨材の粒度, コンクリートの配合 （スランプと配合強度）を選び，さらに鉄筋の形状（異 形の形状による付着強度の差）と打上り高さの要因を加 えて，これらの因子と付着強度との関係について検討し た。それぞれの因子の水準は表一1 亿示したよらな 2 水 準とし, わりつけは $\mathrm{L}_{16}\left(2^{15}\right)$ の直交配列表によった。

表一1 シリーズ II における因子および水準

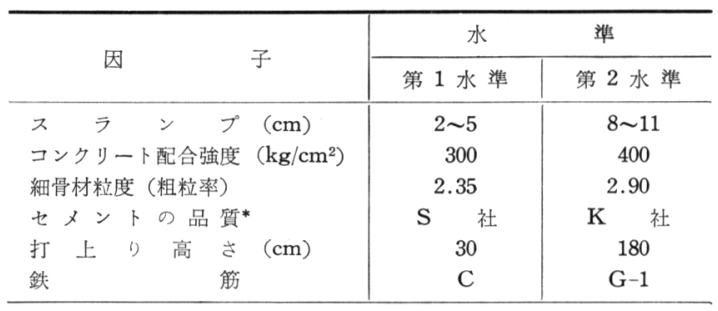

*普通ポルトランドセメント

\section{（2） 供試鉄筋とコンクリート}

実験に用いた異形鉄筋は 表一 2 および 図一1 に示した $\mathrm{A} \sim \mathrm{I}$ の計 15 種である。

試験片は一般の港湾工事に最も多く用いられている D 16 (公称直径 $16 \mathrm{~mm}$ ) SD 35 を標準とした。

シリーズIでは, 表面形状がかなり相違するCと G1 の 2 種の異形鉄筋を用いた。使用したセメントの諸性 質, 細骨材, 粗骨材の物理的性質および用いたコンク リートの配合は 表一3〜6 に示すと㧍りである。

\section{（3）供試体の製作}

コンクリートの練りまぜには容量 $200 l$ の強制練りミ キサを使用した。コンクリートはミキサより排出後, た だちに恒温恒湿室 $\left(20^{\circ} \mathrm{C}, 100 \%\right.$ R.H. $)$ に搬入して供試 体を製作した。

コンクリートの締固めには, 棒状内部振動機を使用し
表一2 鉄筋の種類と形状

\begin{tabular}{|c|c|c|c|c|c|}
\hline 鉄 筇 名 & 規 & 格 & 呼び名 & $\begin{array}{c}\text { フシの高さ } \\
(\mathrm{mm})\end{array}$ & 形 \\
\hline A & SD & 30 & D 16 & 1.1 & 横 フ 之 \\
\hline B & $\mathrm{SD}$ & 35 & D 16 & 0.8 & 横 フ 之 \\
\hline $\mathrm{C}$ & SD & 35 & D 16 & 0.9 & 斜め平行フン \\
\hline $\mathrm{D}$ & SD & 35 & D 16 & 1.3 & 波形フン \\
\hline $\mathrm{E}-1$ & $\mathrm{SD}$ & 35 & D 16 & 0.6 & 横フン，三角筋 \\
\hline $\mathrm{E}-2$ & $\mathrm{SD}$ & 35 & D 16 & 1.1 & 横フン, 三角筋 \\
\hline$F-1$ & $\mathrm{SD}$ & 35 & D 16 & 1.1 & 波形類似フン \\
\hline $\mathrm{F}-2$ & SD & 40 & D 16 & 1.0 & 波形類似フン \\
\hline G-1 & SD & 35 & D 16 & 1.0 & 波形類似フン \\
\hline G-2 & $\mathrm{SD}$ & 40 & D 16 & 0.9 & 波形類似フン \\
\hline $\mathrm{H}$ & $\mathrm{SD}$ & 40 & D 16 & 0.6 & 斜め交差フン \\
\hline$I-1$ & SD & 35 & D 13 & 0.5 & 斜め交差フシ \\
\hline $\mathrm{I}-2$ & SD & 35 & D 16 & 0.7 & 斜め交差フン \\
\hline I -3 & $\mathrm{SD}$ & 35 & D 19 & 1.0 & 斜め交差フン \\
\hline I -4 & $\mathrm{SD}$ & 35 & D 22 & 0.8 & 斜め交差フン \\
\hline
\end{tabular}

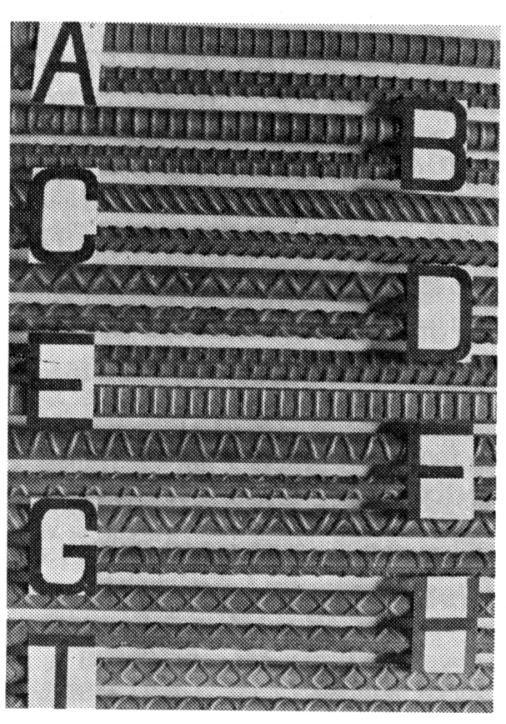

図一1実験に用いた各種異形鉄筋

た。打込み高さ $30 \mathrm{~cm}$ の供試体は 2 層に分けた。打上 り高さ $180 \mathrm{~cm}$ の供試体は 3 層に分けて打込んだ。

シリーズIIでは, 圧縮強度試験用供試体は $\phi 15 \mathrm{~cm}$ の

表一3 セメントの諸 性 質

\begin{tabular}{|c|c|c|c|c|c|c|c|c|c|c|c|c|c|c|c|}
\hline \multirow{2}{*}{ ンリーズ } & \multirow{2}{*}{\multicolumn{2}{|c|}{$\begin{array}{l}\text { セxントの } \\
\text { 種 類 }\end{array}$}} & \multirow[b]{2}{*}{ 比 重 } & \multicolumn{2}{|c|}{ 粉 末 } & \multicolumn{3}{|c|}{ 凝 } & \multirow{2}{*}{ 安定性 } & \multicolumn{3}{|c|}{ 曲 $\underset{\left(\mathrm{kg} / \mathrm{cm}^{2}\right)}{\stackrel{\text { 強 }}{(2)}}$} & \multicolumn{3}{|c|}{ 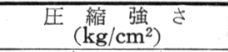 } \\
\hline & & & & $\begin{array}{l}\text { フレーンン } \\
\left(\mathrm{cm}^{2} / \mathrm{g}\right)\end{array}$ & $\begin{array}{l}88 \mu \\
(\%)\end{array}$ & $\begin{array}{l}\text { 水 }(\%) \\
\text { 量 }\end{array}$ & $\begin{array}{l}\text { 始 発 } \\
\text { (時-分) }\end{array}$ & $\begin{array}{l}\text { 終 結 } \\
\text { (時-分) }\end{array}$ & & 3 日 & 7 日 & 28 日 & 3 日 & 7 日 & 28 日 \\
\hline I & $\mathrm{S}$ & 社 & 3.18 & 3050 & 2.5 & 27.5 & $2-26$ & $3-21$ & 良 & 32.1 & 48.0 & 71.9 & 127 & 220 & 413 \\
\hline \multirow[b]{2}{*}{ II } & $\mathrm{S}$ & 社 & 3.18 & 3050 & 2.5 & 27.5 & $2-26$ & $3-21$ & 良 & 32.1 & 48.0 & 71.9 & 127 & 220 & 413 \\
\hline & $\mathrm{K}$ & 社 & 3.15 & 3290 & 1.2 & 27.2 & $2-25$ & $3-26$ & 良 & 30.4 & 47.2 & 68.5 & 135 & 237 & 395 \\
\hline
\end{tabular}

表一4 細 骨 材 の 物 理 的 性 質

\begin{tabular}{|c|c|c|c|c|c|c|c|c|c|c|c|c|}
\hline \multirow{3}{*}{ ンリーズ } & \multirow{3}{*}{ 産 } & \multirow{3}{*}{ 種 } & \multirow{3}{*}{ 類 } & \multirow{3}{*}{ 比 重 } & \multirow{3}{*}{$\begin{array}{c}\text { 吸 水 量 } \\
(\%)\end{array}$} & \multicolumn{6}{|c|}{ フルイを通るものの重量百分率 (\%) } & \multirow{3}{*}{ 粗粒率 } \\
\hline & & & & & & \multicolumn{6}{|c|}{ フルイの呼び寸法 $(\mathrm{mm})$} & \\
\hline & & & & & & 5 & 2.5 & 1.2 & 0.6 & 0.3 & 0.15 & \\
\hline I & 神奈川県鹄沼海岸 & \multicolumn{2}{|c|}{-} & 2.56 & 2.8 & 97 & 89 & 81 & 62 & 35 & 5 & 2.31 \\
\hline \multirow{2}{*}{ II } & 静岡県富士川 & 細 & 砂 & 2.65 & 1.7 & 100 & 97 & 92 & 57 & 19 & 0 & 2.35 \\
\hline & 静岡県富士川 & 粗 & 砂 & 2.66 & 2.0 & 99 & 87 & 68 & 42 & 14 & 0 & 2.90 \\
\hline
\end{tabular}


表--5 粗骨材 の 物 理 的性質

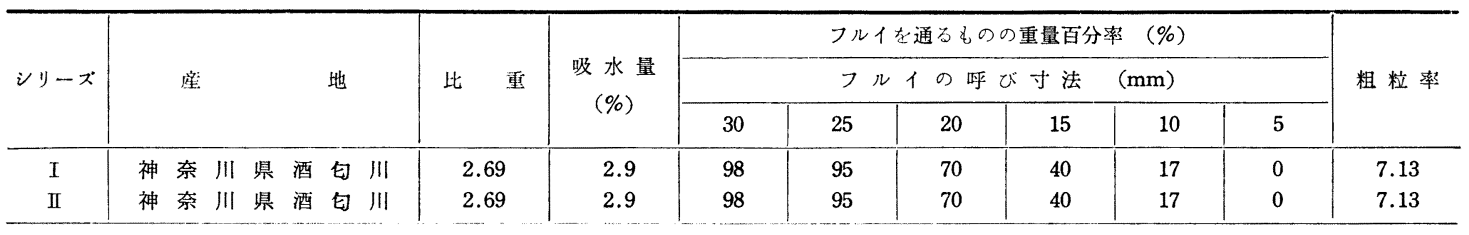

(a) シリーズ I

表一6コンクリートの配合

\begin{tabular}{|c|c|c|c|c|c|c|c|c|c|c|c|}
\hline \multirow{2}{*}{$\begin{array}{c}\text { 粗骨材の } \\
\text { 聫法 } \\
(\mathrm{mm})\end{array}$} & \multirow{2}{*}{$\begin{array}{c}\begin{array}{c}\text { スランプ } \\
(\mathrm{cm})\end{array} \\
\end{array}$} & \multirow{2}{*}{$\begin{array}{c}\text { 空 知 量 } \\
(\%)\end{array}$} & \multirow{2}{*}{$\begin{array}{l}W / C \\
(\%)\end{array}$} & \multirow{2}{*}{$\begin{array}{l}S / A \\
(\%) \\
\end{array}$} & \multicolumn{5}{|c|}{$1 \mathrm{~m}^{3}$ 当りの使用量 $(\mathrm{kg})$} & \multirow{2}{*}{ 備 } & \multirow{2}{*}{ 考 } \\
\hline & & & & & $W$ & $C$ & $S$ & G & $\begin{array}{c}\text { 电り } \\
\text { No. } 8\end{array}$ & & \\
\hline 25 & $8.5 \pm 1.0$ & $4.0 \pm 1.0$ & 53.4 & 36.5 & 155 & 290 & 669 & 1221 & 0.725 & 配合強度 & $\sigma_{28}=270 \mathrm{~kg} / \mathrm{cm}^{2}$ \\
\hline
\end{tabular}

(b) シリーズ II

\begin{tabular}{|c|c|c|c|c|c|c|c|c|c|c|c|c|c|c|}
\hline \multirow{2}{*}{ 配合番号 } & \multicolumn{5}{|c|}{ 因 } & \multicolumn{2}{|l|}{ 子 } & \multirow{2}{*}{$\begin{array}{c}\text { 粗骨材の } \\
\text { (mm) } \\
(\mathrm{mm})\end{array}$} & \multirow{2}{*}{$\begin{array}{l}W / C \\
(\%)\end{array}$} & \multirow{2}{*}{$\begin{array}{l}S / A \\
(\%)\end{array}$} & \multicolumn{4}{|c|}{$1 \mathrm{~m}^{2}$ 当りの使用量 $(\mathrm{kg})$} \\
\hline & \begin{tabular}{|}
$\begin{array}{c}\text { スランプ } \\
(\mathrm{cm})\end{array}$ \\
\end{tabular} & $\mid \begin{array}{l}\text { コンクク } \\
\text { 强度 }\end{array}$ & $\begin{array}{c}リ-下 \text { 配合 } \\
\left(\mathrm{kg} / \mathrm{cm}^{2}\right)\end{array}$ & |細骨材粒度| & セメント & $\left|\begin{array}{c|}\text { 打上り高さ } \\
(\mathrm{cm})\end{array}\right|$ & 鉄 筋 & & & & $W$ & $C$ & $S$ & G \\
\hline $\begin{array}{l}1-1 \\
1-2\end{array}$ & \multirow{4}{*}{$2 \sim 5$} & \multirow{2}{*}{\multicolumn{2}{|c|}{300}} & 2.35 & $\begin{array}{ll}S & \text { 社 } \\
K & \text { 社 }\end{array}$ & $\begin{array}{r}30 \\
180\end{array}$ & $\begin{array}{c}\mathrm{C} \\
\mathrm{G}-1\end{array}$ & 25 & 63 & 41 & 173 & 274 & 785 & 1157 \\
\hline $\begin{array}{l}2-1 \\
2-2\end{array}$ & & & & 2.90 & $\begin{array}{cc}\mathrm{K} & \text { 社 } \\
\mathrm{S} & \text { 社 }\end{array}$ & $\begin{array}{r}30 \\
180\end{array}$ & $\begin{array}{c}\text { G-1 } \\
\text { C }\end{array}$ & 25 & 63 & 43 & 173 & 274 & 835 & 1106 \\
\hline $\begin{array}{l}3-1 \\
3-2\end{array}$ & & \multirow{2}{*}{\multicolumn{2}{|c|}{400}} & 2.35 & $\begin{array}{ll}\mathrm{K} & \text { 社. } \\
\mathrm{S} & \text { 社 }\end{array}$ & $\begin{array}{r}30 \\
180\end{array}$ & $\begin{array}{c}\text { G-1 } \\
\text { C }\end{array}$ & 25 & 50 & 38 & 173 & 346 & 711 & 1170 \\
\hline $\begin{array}{l}4-1 \\
4-2\end{array}$ & & & & 2.90 & $\begin{array}{ll}S & \text { 社. } \\
\mathrm{K} & \text { 社 }\end{array}$ & $\begin{array}{r}30 \\
180\end{array}$ & $\begin{array}{c}C \\
G-1\end{array}$ & 25 & 50 & 41 & 173 & 346 & 764 & 1124 \\
\hline $\begin{array}{l}5-1 \\
5-2\end{array}$ & \multirow{4}{*}{$8 \sim 11$} & \multirow{2}{*}{\multicolumn{2}{|c|}{300}} & 2.35 & $\begin{array}{ll}\mathrm{K} & \text { 社 } \\
\mathrm{S} & \text { 社 }\end{array}$ & $\begin{array}{r}30 \\
180\end{array}$ & $\begin{array}{c}\mathrm{C} \\
\mathrm{G}-1\end{array}$ & 25 & 63 & 41 & 183 & 291 & 769 & 1132 \\
\hline $\begin{array}{l}6-1 \\
6-2\end{array}$ & & & & 2.90 & $\begin{array}{ll}S & \text { 社 } \\
\mathrm{K} & \text { 社 }\end{array}$ & $\begin{array}{r}30 \\
180\end{array}$ & $\begin{array}{c}\text { G-1 } \\
\text { C }\end{array}$ & 25 & 63 & 43 & 183 & 291 & 819 & 1081 \\
\hline $\begin{array}{l}7-1 \\
7-2\end{array}$ & & \multirow{2}{*}{\multicolumn{2}{|c|}{400}} & 2.35 & $\begin{array}{ll}S & \text { 社 } \\
K & \text { 社 }\end{array}$ & $\begin{array}{r}30 \\
180\end{array}$ & $\begin{array}{c}\text { G-1 } \\
\text { C }\end{array}$ & 25 & 50 & 38 & 183 & 366 & 694 & 1143 \\
\hline $\begin{array}{l}8-1 \\
8-2\end{array}$ & & & & 2.90 & $\begin{array}{ll}\mathrm{K} & \text { 社 } \\
\mathrm{S} & \text { 社 }\end{array}$ & $\begin{array}{r}30 \\
180\end{array}$ & $\begin{array}{c}\mathrm{C} \\
\mathrm{G}-1\end{array}$ & 25 & 50 & 41 & 183 & 366 & 745 & 1092 \\
\hline
\end{tabular}

円柱形で，高さ $30 \mathrm{~cm}$ の鋼製型わくを水密的に何段で も重ね得る構造のものを 6 段重ねとした型わくを用いて 製作した。このほか, 各試験条件ごとに $\phi 15 \times 30 \mathrm{~cm}$ の 標準供試体 4 個製作し， 3 個は強度試験に供し, 残りの 1 個は打上り高さ $30 \mathrm{~cm}$ のときのブリージング試験に 供した。打上り高さ $180 \mathrm{~cm}$ の供試体でも上面でブリー ジング量を測定した。コンクリートの表面はこて で均したあと，湿紙とガラス板でおおい，水分の 蒸発を防止した。これらの供試体は，材令 1 2 日で脱型したあと,コンクリートカッターで長さ $30 \mathrm{~cm}$ に切断し所定の材令まで $20^{\circ} \mathrm{C}$ で水中養生 した。

付着強度試験用供試体は断面i $15 \times 15 \mathrm{~cm}$ の角 柱形である。シリーズIでは鋼製型わくを使用し た。シリーズ川では木製型わくを用い打上り高さ $180 \mathrm{~cm}$ の場合には，あらかじめ組み立てた高さ $60 \mathrm{~cm}$ の木製型わくを 3 段積みとして打込んだ。 型わくと鉄筋埋込みの要領を図一2に示す。上ifii
仕上げ後の処理は圧縮強度試験用供試体と同様である。 材令 $1 \sim 2$ 日後で脱型した供試体は， $15 \times 15 \times 15 \mathrm{~cm}$ の 立方供試体になるように切断し, 所定の材令まで $20^{\circ} \mathrm{C}$ で水中養生した。

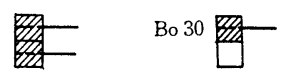

$15 \times 15 \times 30 \mathrm{~cm} \quad 15 \times 15 \times 30 \mathrm{~cm}$ 付有強度試験用供試体

(a)シリーズI
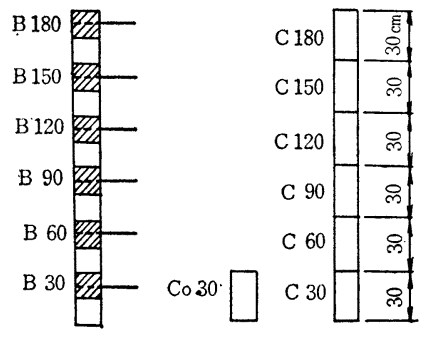

$15 \times 15 \times 180 \mathrm{~cm} \quad \phi 15 \times 30 \mathrm{~cm} \quad \phi 15 \times 180 \mathrm{~cm}$ 付着強度試験用供試体

圧縮強度試験用供試体

(b)シリーズ II 


\section{(4) 試験 方法}

ブリージングは, JIS A 1123-1957 “コンクリートの ブリージング試験方法”に準じて試験した。コンクリー ト上面に留まったブリージング水をメスシリンダーに集 水し測定後ただちに水にもどした。

付着強度は，ASTM C 234-62 に準じた引き抜き試験 方法により試験した。シリーズIでは付着強度は, 付着 特性を明確に表示するために, できるだけ大きい值を基 準量とする必要があることから, 次式を用いて求めた。

$$
\tau_{0}=\frac{\tau_{05}+\tau_{10}+\tau_{15}}{3}
$$

ここで, $\tau_{05}, \tau_{10}, \tau_{15}$ は, 荷重端における滑り量がそれ ぞれ $0.05,0.10,0.15 \mathrm{~mm}$ のときの付着志力度である。

この実験において鉄筋の自由端における滑り量を基準 にして求めた付着強度は, 荷重端における滑り量を基準 にして求めた付着強度との間には直線的な関係が見られ 滑り量を適当に選択すれば自由端における付着強度をも とにして評価し得ることが明らかとなった ${ }^{1)}$ ので，シ リーズIIでは次式を用いて，付着強度を求めた。

$$
\tau_{0}^{\prime}=\frac{\tau_{005}{ }^{\prime}+\tau_{010^{\prime}}+\tau_{015}{ }^{\prime}}{3}
$$

ここで, $\tau_{005}{ }^{\prime}, \tau_{010}{ }^{\prime}, \tau_{015}{ }^{\prime}$ は, 自由端における滑り量が それぞれ $0.005,0.010,0.015 \mathrm{~mm}$ のときの付着応力度 である。

\section{3. 高さ $30 \mathrm{~cm}$ のコンクリート柱に水平に埋込 んだ異形鉄筋の付着強度}

\section{(1) 試 験 結 果}

表一7 は, シリーズエにおいてコンクリートの圧縮強
度が $\sigma_{28}=280 \mathrm{~kg} / \mathrm{cm}^{2}$ のときの鉄筋とコンクリートの付 着強度の試験結果を示したものである。

\section{（2）水平上筋と水平下筋の付着強度比}

異形鉄筋の付着強度は, 埋込み位置と鉄筋径によって かなり相違するようである。本実験結果によれば D 16 の水平上筋の付着強度は, 水平下筋の付着強度の 60 $80 \%$ 程度であって, ブリージング水が鉄筋の下側面に滞 留し, コンクリートとの付着を阻害する程度が, 鉄筋下 方のコンクリート層の厚さによって異なることが主たる 原因と考えられる。

鉄筋径 D 13 と D 22 の水平上筋と水平下筋の付着強 度比は，それぞれ $43 \% ， 66 \%$ であって，細径の鉄筋ほ ど付着強度の低下率が増大するようである。

表一7 では同時に製作した $15 \times 15 \times 15 \mathrm{~cm}$ の立方供 試体に垂直に埋込んだ異形鉄筋（以下これを垂直筋と呼 ぶ）の付着強度を表示したが，これによると，水平下筋 の付着強度は垂直筋のそれの 66 88\% (平均 77\%), 水 平上筋では, 同比は 39〜64\% (平均 54\%) であった。

\section{4. 高さ $180 \mathrm{~cm}$ のコンクリート柱に水平に埋込 んだ異形鉄筋の付着強度}

\section{(1) 試 験 結 果}

シリーズIIの試験結果は, 表一8 に示したとおりであ る。因子と交互作用はいずれも危険率 10\%を基準とし て有意差を検定した。圧縮強度, 付着強度は打上り高さ $180 \mathrm{~cm}$ に扔けるコンクリート柱の各層（C 30〜C 180, B 30〜B 180）を個々に取り上げて, 打上り高さ $30 \mathrm{~cm}$ の $\mathrm{C}_{0} 30$ および $\mathrm{B}_{0} 30$ と比較した。

\begin{tabular}{|c|c|c|c|c|c|c|c|c|c|c|}
\hline \multirow{2}{*}{ 鉄 筋名 } & \multicolumn{3}{|c|}{ 付着強度 $\left(\mathrm{kg} / \mathrm{cm}^{2}\right)$} & \multicolumn{4}{|c|}{ 鉄筋Aを基準としたときの付着強度比（\%) } & \multicolumn{2}{|c|}{$\begin{array}{l}\text { 垂真筋基準としたとを } \\
\text { 付着强蔗比 }(\%)\end{array}$} & \multirow{2}{*}{ 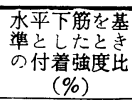 } \\
\hline & 垂 直 & 水平上 & 水平下 & 垂 直 & 水平上 & 水平下 & 平均 & 水平上 & 水平下 & \\
\hline A & 59.8 & 33.2 & 52.4 & 100 & 100 & 100 & 100 & 56 & 88 & 63 \\
\hline B & 61.5 & 39.3 & 50.6 & 103 & 118 & 96 & 106 & 64 & 82 & 78 \\
\hline $\mathrm{C}$ & 56.6 & 35.5 & 48.4 & 95 & 107 & 92 & 98 & 63 & 86 & 73 \\
\hline $\mathrm{D}$ & 57.7 & 29.9 & 43.5 & 96 & 90 & 83 & 90 & 52 & 75 & 69 \\
\hline E-1 & 66.9 & 41.4 & 50.7 & 112 & 125 & 97 & 111 & 62 & 76 & 82 \\
\hline $\mathrm{E}-2$ & 69.3 & 38.0 & 53.5 & 116 & 114 & 102 & 111 & 55 & 77 & 71 \\
\hline $\mathrm{F}-1$ & 47.6 & 28.5 & 37.7 & 80 & 86 & 72 & 79 & 60 & 79 & 76 \\
\hline F -2 & 50.9 & 25.7 & 36.2 & 85 & 77 & 69 & 77 & 50 & 71 & 71 \\
\hline G-1 & 56.3 & 30.1 & 43.8 & 94 & 91 & 84 & 90 & 53 & 78 & 69 \\
\hline G-2 & 55.6 & 27.9 & 38.8 & 93 & 84 & 74 & 84 & 50 & 70 & 72 \\
\hline $\mathrm{H}$ & 48.1 & 18.6 & 31.9 & 80 & 56 & 61 & 66 & 39 & 66 & 58 \\
\hline I -1 & 52.1 & 14.8 & 34.6 & 87 & 44 & 66 & 66 & 28 & 66 & 43 \\
\hline I -2 & 56.6 & 25.2 & 40.9 & 95 & 76 & 78 & 83 & 45 & 72 & 62 \\
\hline I -3 & 62.1 & 28.6 & 51.1 & 104 & 86 & 98 & 96 & 46 & 56 & 56 \\
\hline I -4 & 64.2 & 36.5 & 55.4 & 107 & 110 & 106 & 108 & 57 & 86 & 66 \\
\hline 平均 & - & - & - & $\cdots$ & $\ldots$ & $\ldots$ & $\ldots$ & 52 & 75 & 67 \\
\hline
\end{tabular}

表一7シリーズI の付著強度試験結果 
表一8 シリーズ II の試験結果

\begin{tabular}{|c|c|c|c|c|c|c|c|c|c|c|c|c|c|c|c|c|}
\hline \multirow{2}{*}{ 配合番号 } & \multirow{2}{*}{$\begin{array}{c}\text { スランプ } \\
(\mathrm{cm})\end{array}$} & \multicolumn{2}{|c|}{$\begin{array}{c}\text { フリージンク昌 } \\
\left(\times 10^{-3} \mathrm{~cm}^{3} / \mathrm{km}^{2}\right)\end{array}$} & \multirow{2}{*}{$\begin{array}{c}\sigma_{28} \\
\left(\mathrm{~kg} / \mathrm{cm}^{2}\right)\end{array}$} & \multicolumn{6}{|c|}{ 压縮 强 度 $\left(\mathrm{kg} / \mathrm{cm}^{2}\right)$} & \multicolumn{6}{|c|}{ 付着 強 度 $\left(\mathrm{kg} / \mathrm{cm}^{2}\right)$} \\
\hline & & $\phi 15 \times 30$ & $\phi 15 \times 180$ & & 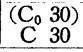 & C 60 & C 90 & $\mathrm{C} 120$ & $\mathrm{C} 150$ & C180 & 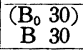 & B 60 & B 90 & $\mathrm{~B} 120$ & $\mathrm{~B} 150$ & B180 \\
\hline $1-1$ & 2.1 & 62 & - & - & (311) & - & - & - & - & - & $(19.3)$ & - & - & - & - . & - \\
\hline $1-2$ & 2.8 & 54 & 113 & 311 & 250 & 289 & 336 & 336 & 297 & 310 & 14.0 & 35.2 & 46.0 & 55.2 & 52.6 & 59.2 \\
\hline $2-1$ & 3.5 & 76 & $\cdots$ & - & (279) & - & -. & - & - & - & $(27.0)$ & - & - & - & - & $-\cdots$ \\
\hline $2-2$ & 4.2 & 76 & 124 & 228 & 197 & 214 & 198 & 228 & 209 & 229 & 5.2 & 14.7 & 49.9 & 40.0 & 34.5 & 34.2 \\
\hline $3-1$ & 3.1 & 34 & & . & (448) & & $\cdots$ & $\cdots$ & $\cdots$ & $\ldots$. & $(34.8)$ & $\ldots$ & - & $\ldots$. & - & - \\
\hline 32 & 2.8 & 51 & 56 & 388 & 347 & 431 & 415 & 433 & 433 & 426 & 15.4 & 40.7 & 66.2 & 39.5 & 64.4 & 41.6 \\
\hline 4-1 & 7.0 & 59 & $\cdots$ & $\cdots$ & (352) & & & & $\ldots$ & . & $(54.5)$ & & - & - & - & - \\
\hline $4-2$ & 7.8 & 45 & 71 & 406 & 342 & 405 & 412 & 404 & 387 & 432 & 24.2 & 53.6 & 73.0 & 53.9 & 63.4 & 44.9 \\
\hline 5-1 & 8.5 & 79 & & $\cdots$ & (303) & - & $-\cdots$ & $\cdots$ & $\cdots$ & … & $(30.7)$ & $\cdots$ & $\ldots$ & $\cdots$ & $\cdots$ & - \\
\hline 5-2 & 8.7 & 88 & 108 & 290 & 208 & 257 & 229 & 236 & 248 & 239 & 23.8 & 30.5 & 68.2 & 58.4 & 48.7 & 34.6 \\
\hline $6-1$ & 9.2 & 79 & $\cdots$ & $\cdots$ & (331) & - & -. & $\cdots$ & - & - & $(20.5)$ & - & - & - & - & - \\
\hline $6-2$ & 9.5 & 79 & 76 & 304 & 239 & 240 & 247 & 273 & 252 & 245 & 14.3 & 68.5 & 37.5 & 46.2 & 55.6 & 47.5 \\
\hline $7-1$ & 8.7 & 11 & - & $\ldots$ & (370) & - & - & - & - & - & $(26.1)$ & - & - & - & - & - \\
\hline $7-2$ & 10.2 & 85 & 20 & 377 & 342 & 370 & 344 & 337 & 330 & 368 & 28.2 & 36.6 & 77.5 & 66.5 & 73.8 & 59.7 \\
\hline $8-1$ & 9.1 & 56 & - & $\cdots$ & (414) & - & - & - & - & - & $(21.8)$ & - & - & - & - & - \\
\hline 8-2 & 9.2 & 56 & 85 & 394 & 385 & 346 & 346 & 403 & 357 & 374 & 23.8 & 39.9 & 44.4 & 58.2 & 71.9 & 71.7 \\
\hline
\end{tabular}

（2）細骨材粒度，配合強度 および 打上り高さがブ リージングにおよぼす影響

図一3 は有意差の認められた因子の母平均の信頼限界 を推定したものである。

細骨材粒度に関してブリージング量を比較すると F. M. $=2.90$ の場合のブリージング量は，F.M.=2.35 の 場合にくらべて約 $30 \%$ 大きく，粗粒率が大きいほど, 換言すれば，粒度の粗いものほどブリージングが多くな る傾向を示している。このような傾向は注入モルタルの 場合にも認められ, 粒子の細かくなるに伴って比表面積 が増し, 保水能力も増えてブリージングが減少するもの と思われる5)。

配合強度が $400 \mathrm{~kg} / \mathrm{cm}^{2}$ のコンクリートのブリージン グ量は配合強度 $300 \mathrm{~kg} / \mathrm{cm}^{2}$ のものに比較して, その平 均值で約 $45 \%$ 減少した。一方, スランプの主効果およ びスランプとコンクリート配合強度の交互作用は必ずし も有意性を示していない。このように，見かけ上，配合

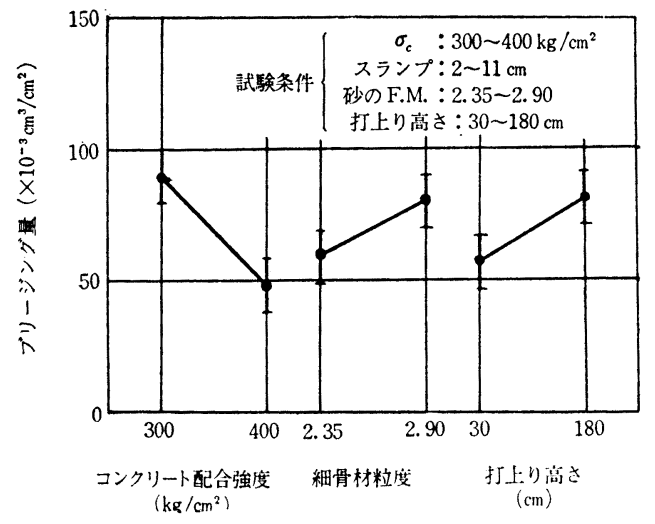

図一3 ブリージング量に有意差を与えた因子と 試験結果の信頼限界（危険率 10\%)
強度がブリージング量と最も密接な関係を示したのはつ ぎのような理由によるものと思われる。すなわち，比較 したスランプ約 $5 \mathrm{~cm}$ の相違は, 単位水量を $10 \mathrm{~kg}$ 程 度変化させるだけであるが，これに反し，配合強度 100 $\mathrm{kg} / \mathrm{cm}^{2}$ の増加は単位セメント量約 $70 \mathrm{~kg}$ の増加に相当 し，本試験で取り上げた配合条件の範囲では，前段で述 ベたような理由により単位水量の変化に比較して, 単位 セメント量の変化がブリージング量により大きな影響を およぼしたためと考えられる。

コンクリートの打上り高さについてブリージング量を 比較すると $30 \mathrm{~cm}$ と $180 \mathrm{~cm}$ とでは, ブリージング量 は約 $30 \%$ 変化し, 打上り高さの増加に伴ってブリージ ング量も増加する傾向を示している。しかし, 絶対量 は，それぞれ $0.057 \mathrm{~cm}^{3} / \mathrm{cm}^{2}$ および $0.082 \mathrm{~cm}^{3} / \mathrm{cm}^{2}$ で あり，その差は，打上り高さの差にくらべて大きいとは いいがたい。ブリージング水が滞留して強度等に影響を およぼすような層の厚さはコンクリート打上り面より一 定の深さに限られるもののようである。

\section{（3）打上り高さが圧縮強度におよぼす影響}

打上り高さ $180 \mathrm{~cm}$ のコンクリート柱の各層の強度は 図一4 に示したとおりで，C 30〜C 150 ではほぼ一定で あるが，最上值 C 180 の強度低下は著しく，C 30〜C 150 の平均值 $324 \mathrm{~kg} / \mathrm{cm}^{2}$ にくらべて, C 180=289 kg/ $\mathrm{cm}^{2}$ で約 $10 \%$ 小さい值が得られた。この上下層の強度 差は軟練りコンクリート（スランプ $15 〜 20 \mathrm{~cm}$ ) を使用 した試験結果による最上層と下層の強度差 ${ }^{2}$ ， あるいは プレパックドコンクリートにおける最上層と下層の強 度差 ${ }^{5)}$ に比較して若干少な目であるが，試験值のバラッ キや試験条件の差も考慮すれば，いずれもほぼ類似した 傾向を示すということができよう。打上り高さ $180 \mathrm{~cm}$ のコンクリート柱と同時に製作した標準供試体の平均值 


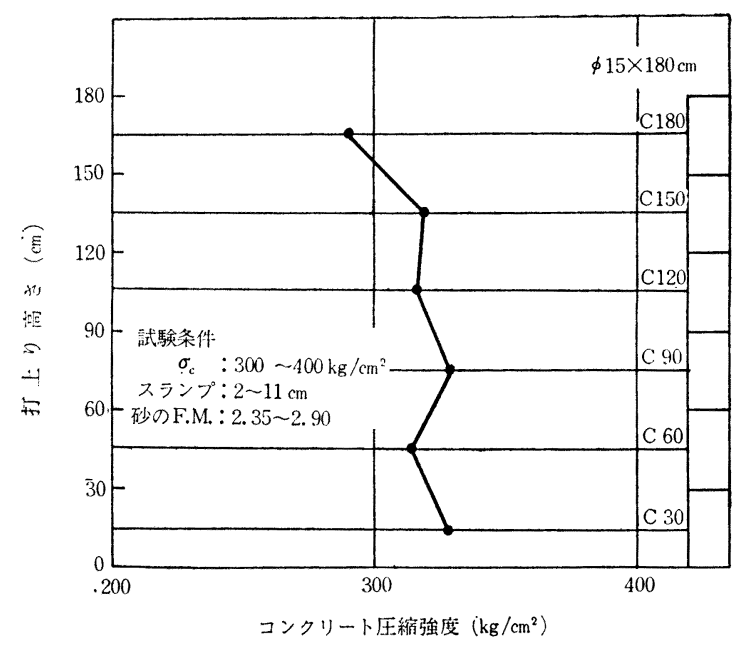

図一4 コンクリート柱 $(\phi 15 \times 180 \mathrm{~cm})$ の各層における 圧縮強度の変化（シリーズ II）

は $337 \mathrm{~kg} / \mathrm{cm}^{2}$ でありコンクリート柱の表層 $30 \mathrm{~cm}$ を除 く各部の強度の平均值とほぼ一致する。このような, 表 層部分の強度低下はブリージングの影響によるもので， ブリージングによって上昇した水が表層付近に滞留して 水セメント比が増し, 強度が減少するものと思われる。

\section{（4）配合強度および打上り高さが付着強度におよぼ す影響}

表一9 はコンクリートの配合強度を比較因子としたと きの付着強度の変化をまとめたものである。これより， 水平に埋込んだ鉄筋の付着強度はコンクリート配合強度 が $300 \mathrm{~kg} / \mathrm{cm}^{2}$ から $400 \mathrm{~kg} / \mathrm{cm}^{2}$ に増加すると $10 \mathrm{~kg} / \mathrm{cm}^{2}$ 程度増加するもののようである。

図一5 は，コンクリート柱各層の付着強度の変化を図 示したもので, B 30〜B 120 の付着強度はほぼ一定（平

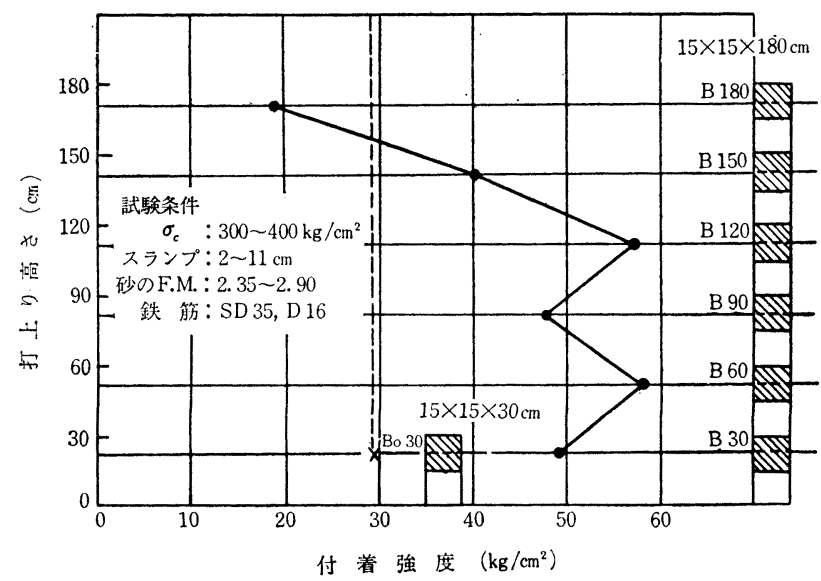

図一5 コンクリートの打上り高さの相连による 付着強度の変化（シリーズ II）
表一9 コンクリートの配合強度の差が 付着強度におよぼす影響

\begin{tabular}{|c|c|c|c|}
\hline \multirow{2}{*}{ 供 試 体 } & \multicolumn{2}{|c|}{ 平均值 $\left(\mathrm{kg} / \mathrm{cm}^{2}\right)$} & \multirow{2}{*}{$\begin{array}{c}\begin{array}{c}\text { 差 } \\
\left(\mathrm{kg} / \mathrm{cm}^{2}\right)\end{array} \\
\end{array}$} \\
\hline & $\begin{array}{c}\sigma_{c}=300\left(\mathrm{~kg} / \mathrm{cm}^{2}\right) \\
\text { の 場 合 }\end{array}$ & $\mid \begin{array}{c}\sigma_{c}=400\left(\mathrm{~kg} / \mathrm{cm}^{2}\right) \\
\text { の 場 合 }\end{array}$ & \\
\hline $\mathrm{B}_{0} 30, \quad \mathrm{~B} 30$ & 19.4 & 28.6 & 9.2 \\
\hline $\mathrm{B}_{0} 30, \quad$ B 60 & 30.8 & 38.5 & 7.7 \\
\hline $\mathrm{B}_{0} 30, \quad$ B 90 & 37.4 & 48.9 & 11.5 \\
\hline $\mathrm{B}_{0} 30, \quad \mathrm{~B} 120$ & 37.2 & 43.8 & 6.6 \\
\hline $\mathrm{B}_{0} 30, \quad \mathrm{~B} 150$ & 36.1 & 51.3 & 15.2 \\
\hline $\mathrm{B}_{0} 30, \quad \mathrm{~B} 180$ & 34.1 & 44.4 & 10.3 \\
\hline 平胡 值 & $\cdots$ & $\cdots$ & 10.1 \\
\hline
\end{tabular}

均值 $52.9 \mathrm{~kg} / \mathrm{cm}^{2}$ ) であるが，B 150 は $40 \mathrm{~kg} / \mathrm{cm}^{2}$ で約 $15 \mathrm{~kg} / \mathrm{cm}^{2}$ 減少し, 最上層では B 30〜B 120 の平均值の 約 $1 / 3$ に減少する。図一5 の破線で示した試験值は，打 上り高さ $30 \mathrm{~cm}$ のコンクリート柱の水平上筋の付着強 度であるが，これは B 30 の約 $60 \%$ である。表一7に よると, 鉄筋 C と $\mathrm{G}-1$ の水平上筋の付着強度は水平下 筋の付着強度の約 $65 \%$ であって，付着強度の減少が表 層部分に限定されることでは共通している。

本試験に用いた型わくは木製で，この型わくがコンク リートの沈下収縮やブリージングを拘束した程度は，鋼 製型わくを用いた圧縮強度試験の場合よりかなり大きい と思われる。したがって, 付着強度と圧縮強度試験の結 果を同列において論ずることはできないが，以上に述べ たところを総括すれば，打上り高さの増加に伴う付着強 度の減少は主としてブリージングの影響によるもので, その影響を受ける部分は表層の $0 \sim 60 \mathrm{~cm}$ 程度に限定さ れるようである。

\section{5. 結 論}

コンクリートの打上り高さが付着強度におよぼす影響 を明らかにするために $15 \times 15 \times 30 \mathrm{~cm}$ および $15 \times 15 \times$ $180 \mathrm{~cm}$ のコンクリート柱を製作し，水平に埋込 んだ異形鉄筋とコンクリートの付着強度を引抜き 試験方法によって求めるとともに，ブリージング および圧縮強度試験を実施した。この結果を要約 すると本実験の範囲内で以下のことがいえると思 われる。

（1）表面形状や断面形状の相違する 15 種の 異形鉄筋を用いて 試験した結果， $15 \times 15 \times 30 \mathrm{~cm}$ 供試体に水平に埋込んだ上下層の鉄筋の付着強度 比はほぼ70\%であった。

（２）コンクリートのブリージングはその打上 り高さによって変化し, 打上り高さが増加すると ブリージングも増加するが，その増加の割合は打 上り高さの増加の割合ほど大きくなく，ブリージ ングが強度に影響する領域はコンクリート上面よ 
り比較的浅い表層に限定されるもののようである。

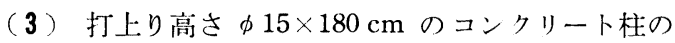
上部 $30 \mathrm{~cm}$ を除く各部の圧縮強度はほぼ一定であり, $\phi 15 \times 30 \mathrm{~cm}$ の標準供試体の強度とほぼ一致した。コン クリート柱最上層 $30 \mathrm{~cm}$ の強度は, 標準供試体強度の $90 \%$ 程度であった。

(4) 打上り高さの大きいコンクリートに水平に埋込 んだ鉄筋の付着強度は，表層 $0 \sim 60 \mathrm{~cm}$ の部分を除く上 高さに関係なくほぼ一定であるが，上面より $30 \sim 60 \mathrm{~cm}$ の区間で多少低下し，表層 0 30 cm の間では下層の 平均值の $1 / 3$ 程度まで減少する。

(5) 以上から，コンクリートの 1 回の打上り高さを 制限することによって, 水平上筋の付着強度の低下を防 止し得ないことは明らかである。また皮平上筋の付着強 度を増加させるために, コンクリート打設後, 真空処 理, 再振動等の処理を施すことも実際的でないことが多 い。コンクリートの打継目の位置は, 個々の, 工事現場 の施工条件に応じて設けられるため, 一様でなく, 部材 設計の段階では不明の場合も多い。したがって鉄筋の埋 込み位置によって許容付着強度を変えることは, 妥当な 方法とはいえない。
（6）したがって，許容付着応力度をコンクリートの 打上り高さの大きいときの水平鉄筋の付着強度の低下を 考慮して安全側に定める方法が最も適当と思われる。本 実験では高さ $180 \mathrm{~cm}$ のコンクリート柱における付着強 度の減少は上層 $60 \mathrm{~cm}$ の範囲に限定されることが明ら かとなったが，この点についてはさらに検討する必要が あろう。

\section{引用文 献}

1）赤塚雄 “関 博：“港湾構造物に抄汀る高張力異形鉄 筋の使用方法浮関する调查研究（第 1 報)”, 港湾技術研 究所報告, 5 巻 15 号, pp $1 \sim 80,1966$ 年 9 月.

2）児玉武二：“打設コンクリートの高さによる性質の変化 について”，セメント技術年報，XVIII，pp 386〜394， 1964 年.

3）加藤六美：“鉄筋の付着ならびに䇥廈に関する 2,3 の注 意”, 日本建築学会研究報告, 22 号, p. 111, 1953 年 5 月.

4）赤塚雄三・関 博：“港湾構造物における高張力異形鉄 筋の使用方法に関卞る調査研究（第 2 報）”，港湾技術研 究所報告, 7 巻 1 号, pp 25 45, 1968 年 3 月.

5）赤塚雄三：“港湾工事におけるプレパックドコンクリー 卜の施工管理に関する基礎研究”, 港湾技術研究所報告, 4 巻 6 品, pp 1 94, 1965 年 7 月.

(1968.9.13 - 受付) 